\title{
Innovation Ecosystems vs. Innovation Systems in Terms of Collaboration and Co-creation of Value
}

\author{
Nataliya Smorodinskaya \\ Inst of Economics, RAS \\ smorodinskaya@gmail.com
}

\author{
Daniel Katukov \\ Inst of Economics, RAS \\ dkatukov@gmail.com
}

\author{
Kaisa Still \\ VTT of Finland \\ kaisa.still@vtt.fi
}

\begin{abstract}
In this paper, we explore the relevance of the term "innovation ecosystem" to describe dynamic collaborative networks of people and organizations formed around projects with an innovation objective. We present a survey of literature reviews on ecosystems studies to clarify typical features and interpretations of innovation ecosystems, and we highlight differences in terms of collaboration and value co-creation. We explore ecosystem thinking and illustrate patterns of innovation ecosystems by describing the structure of regional clusters, global value chains and platforms. We offer policy insights on the role of governments in stimulating innovation ecosystems and innovationconducive environments.
\end{abstract}

\section{Introduction}

The concept of innovation ecosystems has emerged in early 2000 s to meet the demands of emerging knowledge-based economies, in which the production of innovations and the associated development processes are increasingly non-linear and network-based [1]. This concept has remarkably enriched the idea of innovation systems, coined in the industrial era in the research streams of Freeman, Lundvall, Nelson, and their followers [2-6]. In the 1990s, national or regional innovation systems were seen as static structures regulated by government bodies, with successful performance depending on a critical mass of involved actors and intentional infrastructure [1]. As a departure, innovation ecosystems of the 2000s are considered dynamic and agile collaborative structures that enjoy self-governance as a necessary prerequisite for interactive innovation $[7,8]$. This approach is now applied in innovation policies of many developed and developing nations [9].

Meanwhile, some scholars and experts still seriously doubt whether the introduction of the term 'ecosystem', adding "eco-" to "system", is justified. In particular, some papers argue that though writers on "innovation ecosystems" have added some valuable ideas to the innovation discussion, appending "eco-" to "innovation systems" adds nothing of substance. Rather, "innovation ecosystem" is a faulty analogy to natural ecosystems [10]. A discussion on this problem of a better terminology opened in the literature quite recently.

Against this background our paper is an attempt to make a contribution to such discussion. With the updated thinking of innovation (for example by the World Economic Forum) [1], we conduct a review of literature published from 2005 to 2016 on ecosystems, concentrating on innovation ecosystems and acknowledging the related terms of business ecosystem, software ecosystem, industrial ecosystem, digital business ecosystem, entrepreneurship ecosystem, and knowledge ecosystem. We aim to clarify typical features of innovation ecosystems as compared to systems and to highlight the advantages of an ecosystemic mode of producing innovations, while picking up interpretations and definitions both from economic and business literature.

\section{On the definition and the variety of ecosystems in literature}

In the updated version of the Global Competitiveness index (GCI), the World Economic Forum draws from findings in the literature, and argues in GCI that innovation now means not only technological innovation but, in a broader notion, an "ecosystem" (environment) conducive to the generation of ideas and their implementation in the form of new products, services, and processes in the global marketplace [1]. This approach can be further described with three important details: the wider-scope of innovation, the innovation-conducive environment, and various studies on ecosystems.

Firstly, regarding the scope of innovation, new ideas can be generated by formal scientific R\&D; they can also result from non-R\&D activities that do not require fixed research costs yet increase the efficiency with which a good or service is produced (such as innovations in managerial and organizational 
techniques, personnel, accounting, work practices, etc.) The implementation of such ideas may be commercial and non-commercial (the latter often treated as "softer" innovation.)

Table 1. Literature reviews on the variety of ecosystems, 2005-2016

\begin{tabular}{|c|c|c|}
\hline Review & Review source & Review result \\
\hline (Peltoniemi, 2005) [11] & $\begin{array}{l}\text { Literature review and conceptual } \\
\text { analysis of business ecosystem as } \\
\text { an organizational population model }\end{array}$ & $\begin{array}{l}\text { Dynamics of conscious choice and limited } \\
\text { knowledge of an individual organization and } \\
\text { from the interconnected-ness and feedback } \\
\text { loops of an organization's population; } \\
\text { differences in cluster and value networks }\end{array}$ \\
\hline $\begin{array}{l}\text { (Manikas \& Hansen, 2013) } \\
\text { [13] }\end{array}$ & $\begin{array}{l}90 \text { papers relevant to software } \\
\text { ecosystem(s) }\end{array}$ & $\begin{array}{l}\text { The software industry is moving towards } \\
\text { software ecosystems with platforms like } \\
\text { Google Android and Apple iOS }\end{array}$ \\
\hline $\begin{array}{l}\text { (Pilinkienė \& Mačiulis, } \\
\text { 2014) [14] }\end{array}$ & $\begin{array}{l}\text { Literature review of ecosystem } \\
\text { analogies: industrial ecosystem, } \\
\text { innovation ecosystem, business } \\
\text { ecosystem, digital business } \\
\text { ecosystem, entrepreneurship } \\
\text { ecosystem }\end{array}$ & $\begin{array}{l}\text { Ecosystem analogies have various scopes } \\
\text { and objectives having an impact on micro- } \\
\text { level, associated with actions of internal } \\
\text { actors; (eco)system can be a significant } \\
\text { determinant of sustainable economic } \\
\text { development }\end{array}$ \\
\hline (Gawer, 2014) [15] & $\begin{array}{l}\text { Review of management research on } \\
\text { technological platforms: industrial } \\
\text { economics and engineering design }\end{array}$ & $\begin{array}{l}\text { Platforms operate along an organizational } \\
\text { continuum, including firms, supply chains, } \\
\text { and industry ecosystems }\end{array}$ \\
\hline $\begin{array}{l}\text { (Gawer \& Cusumano, } \\
\text { 2014) [16] }\end{array}$ & $\begin{array}{l}\text { Platform-based ecosystem } \\
\text { innovation; review of research on } \\
\text { internal and external platforms }\end{array}$ & $\begin{array}{l}\text { A critical issue for managers is to learn to } \\
\text { manage the evolution of their industry } \\
\text { platforms and accompanying ecosystems } \\
\text { and make interrelated technological and } \\
\text { business decisions }\end{array}$ \\
\hline $\begin{array}{l}\text { (Thomas, Autio, \& Gann, } \\
\text { 2014) [17] }\end{array}$ & $\begin{array}{l}183 \text { publications of platforms in } \\
\text { management context }\end{array}$ & $\begin{array}{l}\text { Four streams of platform research identified: } \\
\text { organizational capability, product family, } \\
\text { market intermediary and technology system }\end{array}$ \\
\hline $\begin{array}{l}\text { (Kortelainen \& Järvi, } \\
\text { 2014) [18] }\end{array}$ & $\begin{array}{l}72 \text { empirical articles on ecosystems } \\
\text { in a business context }\end{array}$ & $\begin{array}{l}\text { Research on ecosystems is still a long way } \\
\text { from the stage of theory testing (i.e., using } \\
\text { multivariate statistical methods) or of } \\
\text { replication studies across ecosystems }\end{array}$ \\
\hline (Valkokari, 2015) [19] & $\begin{array}{l}\text { Review of types of business, } \\
\text { innovation and knowledge } \\
\text { ecosystems and the relationships } \\
\text { between them }\end{array}$ & $\begin{array}{l}\text { In order to survive and thrive in an } \\
\text { ecosystem, a variety of forms of interaction } \\
\text { are required; the interaction between various } \\
\text { types of ecosystems is an unexplored area }\end{array}$ \\
\hline $\begin{array}{l}\text { (Suominen, Seppänen, \& } \\
\text { Dedehayir, 2016) [20] }\end{array}$ & $\begin{array}{l}4681 \text { publications to look at } \\
\text { innovation systems literature, } 427 \\
\text { ecosystem research articles }\end{array}$ & $\begin{array}{l}\text { The literature on national, regional and } \\
\text { technological innovation systems, as well as } \\
\text { literature on corporate competitiveness and } \\
\text { the ecosystem approach, has both shared and } \\
\text { divergent intellectual roots }\end{array}$ \\
\hline $\begin{array}{l}\text { (Aarikka-Stenroos, Peltola, } \\
\text { Rikkiev, \& Saari, 2016) } \\
{[21]}\end{array}$ & $\begin{array}{l}\text { Systematic content analysis of } 157 \\
\text { articles of innovation and business } \\
\text { ecosystems }\end{array}$ & $\begin{array}{l}\text { Multidisciplinary perspectives exist on } \\
\text { ecosystem phenomenon; research gaps exist, } \\
\text { including a gap in policy-making; the } \\
\text { business ecosystem stream is dominant }\end{array}$ \\
\hline
\end{tabular}

Source: Authors' elaboration

Secondly, an innovation-conducive environment, comprised of ecosystems and networks, can increase the likelihood that "softer" innovation takes place. This environment encourages collaboration, connectivity, critical and creative thinking, diversity, and confrontation across different visions and angles. By bringing new products and services to market, 
such ecosystems and networks foster productivity though embedded technology, with efficiency gains.

Thirdly, to achieve a complete picture of an innovation-conducive environment one needs to consider both economic literature (which focuses more on system incentives to spur idea generation at the aggregate level) and business literature (which identifies important factors that generate innovative companies and/or motivate them to innovate).

To this end, and particularly to explore the contemporary perception of innovation ecosystems, we examined relevant scholarly literature in the field of management and economics. We found eleven (11) literature reviews, identified through previous literature reviews themselves. For example, Kortelainen and Järvi [18] acknowledge seven primary reviews, while Valkokari [19] draws from the review by Thomas, Autio and Gann [17]. In addition, participation in scientific conferences allowed us to include other very recent reviews. The range of primary sources covered by reviews during the 2005 to 2016 period is diverse, as some are based on tens of scholarly articles, others are based on 100+ articles, and one even considers close to 5000 publications, as shown in Table 1.

Our overarching survey has highlighted a broad variety of related terms, used simultaneously in literature to describe organizational continua or network interactions. Particularly, there are business ecosystems, software ecosystems, platforms, industrial ecosystems, digital business ecosystems, entrepreneurship ecosystems and knowledge ecosystems; in addition, start-up ecosystem is mentioned [21]. Overall, these entities are seen as vital in sustainable economic development [14].

Our findings confirm that the ecosystem idea is often applied without clear definitions [19] and that there is increased conceptual ambiguity of the terminology [20]. Terms denoting different types of ecosystems are often used interchangeably [21], although some differences between biological and business ecosystems are articulated [11, 12, 14]. It has been noted that research on ecosystems is still a long way from the stage of theory testing [18].

\section{Synthesis for interpreting innovation ecosystems}

In previous writings, we viewed innovation ecosystems as networks of sustainable linkages between individuals and organizations, which emerge from a shared vision of desired transformations and provide an economic context (milieu) to catalyze innovation and growth [22]. As applied to the variety of inter-firm or inter-organizational networks, this definition implies innovation ecosystems are oriented either to the direct co-creation of innovations or to the formation of innovation-supportive milieu [23].

As our literature review shows, innovation ecosystems may be treated both as business networks and as communities meant for innovation. They may assume different scale and design, functioning as regional innovation hubs, nation-wide innovation communities, local inter-firm networks, very small network-based ad-hoc groups of individuals, or global wide networks [7].

However, neither geography nor industry sector expose the essence of innovation ecosystems as compared to systems. Noticeably, in management studies, one of the primary motivations for addressing the ecosystem concept has been the desire to explore self-organizing properties of natural ecosystems [24]. In studies on innovation dealing with generation and implementation of new ideas, ecosystems are usually considered a means for cocreation and market introduction of inventions [1]. Literature on economic competitiveness incorporates the idea of ecosystems in the context of the broad impact of digital technologies (IT, ICT) on the changing nature of innovation process, especially regarding implications of non-linear innovation for alternative organizational designs. Such thinking is reflected in modern production systems at all levels (firms, clusters, regions, national economies, global economy).

Summarizing the relevant points in literature, as they highlight the origin and properties of innovation ecosystems, we come to the following conclusion. In the age of non-linear innovation and digital technologies, innovation can be better nurtured within a special, innovation-conducive environment. Such an environment may be seen as an ecosystem meant for co-creation of value through collaboration.

The concept of value co-creation is basically associated with a business strategy focusing on interactive relationships between producers and consumers (the latter are becoming productive workers, or prosumers, who are granted authority by companies to articulate their specific requirements and at times contribute to design considerations). Initially elaborated by the business and market literature, this concept started to gain momentum in the post-2000 period, expanding further in its two dimensions, as both the idea of value co-production and the idea of value-in-use [25].

According to an updated definition, as introduced in management studies, particularly by LSE Enterprise [26], co-creation of value is an active, creative and social process, based on collaboration 
between producers and users, which is initiated by the firm to generate value for customers and compete to pass others in the category (i.e., the Nike approach constitutes a full spectrum of customer involvement and competition). While consumers benefit from greater personalization and value, companies build competitive advantage by turning just-in-time knowledge from customers into just-in-time learning for their organizations. Relationships for co-creation may also be established between and among businesses and service organizations. Such collaboration might include global introduction, competitive analytics and tolerance for inefficiency.

The co-creation concept highlights not only the frequency of interaction, but also the quality of relationships between companies and their customers, or among companies, to determine how knowledge is created, shared and transferred [27]. In terms of modern economics literature, this concept can be applied to the architecture of the innovation-led economy based on customized products. In this sense, the co-creation process may imply the possibility of collaboration between different types of actors across the economy, enabling them to coproduce new goods and values, i.e., innovations.

In turn, collaboration, taken in a broad sense, denotes various forms of interactive communication between networked actors. For example, some experts argue [27] that collaboration is important for both $R \& D$ and non-R\&D innovation but each type uses different networks. In a more exact definition, collaboration is seen as the most developed form of interactive cooperation. It implies that in order to cocreate innovations, networked actors must rely on a common vision, strategy, common identity, and joint obligations [28].

To further explain the term of innovation ecosystems and its implications, we have developed additional perspectives.

\section{1 'Innovation ecosystem' as a metaphor for collaborative innovation networks}

Ecosystems can't be deliberately established as system-like organizations. Rather they emerge as innovation-conducive environments in the course of collaboration among networked actors. Meanwhile, collaborative networks themselves, tailored to cocreation of value in various forms and ways, can and should be treated as modern agile organizations typical of the $21 \mathrm{st}$ century. One of the first descriptions of such dynamic and innovative entities appeared in early 1990s in the "New Society of Organizations" by P. Drucker [29], in which he underlined the ability of such organizations for continual "creative destruction" and predicted their future global domination.

Later, a more exact term of 'collaborative innovation networks' appeared in literature to denote typical organizational forms of production in the age of digital technologies. This term was popularized by Gloor in 2006 [30] and further explored conceptually [31] and empirically [32] by other authors. Such networks may be local, national, transnational or global; they may have different configuration and patterns of collaboration [31]. Their growing proliferation implies that in the $21^{\text {st }}$ century, innovative goods, technologies and values will be typically co-created through collaborations of networked entities that form relatively sustainable ecosystems of actors, linkages and assets [33].

Since innovativeness of networks can be revealed only through their collaboration activities, we can consider them innovation ecosystems and use this term as a metaphor for denoting their specific organizational and functional features, as compared to systems. Ecosystems are tailored to interactive cocreation of values, while systems are not.

Taken as a metaphor of collaborative networks, the term 'innovation ecosystem' provides a highly useful image to draw a difference between the rigid hierarchical design of economic systems in the age of linear development and their dynamic network-based architecture in the $21^{\text {st }}$ century. Hence, this term helps to highlight the newly emerging economic milieu, in which innovative goods and values are created at the level of networks capable of shaping an effective ecosystem. "Eco" stands to emphasize the non-linear nature of innovation and the crucial role of collaboration in producing innovations to achieve sustainable development in non-linear environments.

The ability of collaborative networks to adapt themselves to a non-linear environment implies they assume certain features of complex adaptive systems agility, self-organization, self-governance, and synergy effects [34]. When it comes to such ecosystems as innovation clusters, cluster literature (originated by Porter and followers) directly interprets them as complex dynamic systems, noting their unique synergy effects [35-37].

Also important, collaborative networks that form an ecosystem of actors and linkages to co-create innovations are designed as temporary projects, around a common project idea. For this reason, the emanating network economy is also called a project economy [38], as an alternative to a traditional economy, in which interactions are not necessarily collaborative and long-term systems are intended. Collaborative networks and their ecosystems are distinguished by different design, functional purpose 
and pattern of collaboration. These differences can be easily seen when comparing regional innovation clusters, global value chains and digital platforms.

\subsubsection{Innovation clusters as formalized} innovation ecosystems. Innovation clusters are geographically localized agglomerations of collaborating firms and organizations, which enjoy a highly developed pattern of collaboration, associated with a triple-helix model, i.e. an interactive pairwise collaboration between three types of networked institutional actors, namely companies, research centers and authorities [39]. As follows from cluster literature [37], innovation clusters constitute a special variety of innovation ecosystems, in which triplehelix interactions enable unique economic effects of innovation synergy, or co-creation of innovative goods and services on a continual basis. According to this literature, among the various kinds of collaborative networks only innovation clusters can provide a sustainable rise in productivity based on a continual innovation [40]. Initial systemic findings [41] confirm that successful innovation clusters can function as poles of growth for a given region.

Open innovation clusters are considered the most convenient ecosystem model both for continuous co-creation of innovations and for disseminating them across an economy. These ecosystems are shaped by collaborative partners of various profiles, who are free to join and leave the open cluster network [40]. According to observations [42-44], mature clusters have a sophisticated ecosystem of functional linkages, formed both by deeply embedded actors and by flagship firms that have already expanded beyond the cluster's bounds and are reinvesting money in their business projects

By virtue of the coordinating work of cluster organizations, a co-located group of companies is able to transform itself into a self-governed and selfsustainable network that can achieve innovation synergy. Due to their relationships developed as ecosystems, entities in agile innovation clusters can combine and rapidly recombine their shared assets in varied and novel configurations and, in this way, can flexibly start new venture business projects to meet the rapidly changing market demands. Their "design" is evolved through a combination of market forces, organizational efforts of triple helix actors [45], and value transactions [46].

3.1.2. Global value chains as innovation ecosystems of cross-cluster collaboration. Regional innovation clusters are seeking to develop their specializations in ways that enable them to become geographically localized network nodes of global value chains (GVCs). The latter are the result of globalization, when traded goods and services are no longer produced or consumed within a single country but instead, through dispersion of the production processes and marketing, across several countries. GVCs are now horizontally crossing countries and territories, with value added flows circulating between their cluster nodes. Meanwhile, GVCs themselves constitute a special kind of collaborative networks, and therefore, a kind of ecosystem to cocreate value.

GVCs emerged in the late industrial era due to outsourcing business practices. Initially, they were governed by hierarchic multinationals that were building vertical systems of actors under their control, while looking for expansion in size at local, not yet globalized markets. Nowadays, multinationals tend to become more horizontally dispersed and network-based [47].

One can see a GVC as a horizontally dispersed ecosystem for value co-creation, formed by a network of legally independent and functionally interdependent actors that are collaborating across countries and territories within a common project. The participating actors create initial and intermediary products (knowledge, technologies, goods, services) that move along the chain in an upstream way, generating flows of a consecutively added value, until the final product is co-created and delivered to external customers, embedding productivity into a dynamic cluster ecosystem.

3.1.3. Platforms as ecosystems for value cocreation. Digital platforms are oftentimes regarded as technological systems, as a technical artifact, "as the extensible code-based system that provides core functionality shaped by the modules that interoperate with it, and the interfaces through which they interoperate" [48, p. 677]. Increasingly they are also seen as management and economic concepts, creating value by providing products and services that enable two or more different types of customers to find each other and exchange value [49]. Importantly, the overall value of platform requires players, such as developers who build tools, to operationalize the exchange [50]. Conceptualization of platforms has been developed separately by two streams of academic literature - industrial economics and engineering design.

The industrial economics perspective associates platforms with a new, network type of markets (twosided or multi-sided), focusing on how platforms create value by coordinating transactions between two or more groups of consumers who would not have been able to connect without the platform. This 
literature highlights that platforms generate a virtuous cycle of indirect, or cross-group network effects (the value that consumers and the platform owner can capture increases with increasing customer bases), which dynamically reinforces incumbents' earlygained advantages.

The engineering design perspective views platforms as purposefully designed modular architectures organized around a 'core' (the platform leader) and a 'periphery of users' (which complement the platform leader), providing a respective technological interface between these two sides. This literature posits that platforms can network and coordinate users not just in the role of consumers but first of all in the role of suppliers and innovators, thus helping firms to achieve the economy of scope effects and facilitate innovation [51].

The literature on platforms distinguishes three broad types of platforms, namely platforms within firms (like Sony Walkman's platform servicing constituent sub-units of one firm in consumer electronics), platforms across supply chains, including GVCs (like Boeing's platform for the GVC in aerospace manufacturing, or Renault-Nissan's platform for the GVC in automotive manufacturing), and industry-wide platforms (like Facebook's platform across the sector of social networking) [52]. Industry-wide platforms are considered as generators of the most open ecosystems. They are defined as technological building blocks (technologies, products, or services), which act as a foundation for organized array of interdependent firms (sometimes called an industry "ecosystem") to develop a set of inter-related products, technologies and services [15].

On top of this, there exists a special class of platforms for joint action, tailored to overcome coordination problems and to directly support collaboration in the process of the project realization [52]. These platforms enable cluster participants to better exploit potential linkages among existing capabilities and to make better decisions on investing into new capabilities, taking into account the externalities of such actions across the cluster [53]. These platforms aim to provide innovation synergy effects that lead to individual and aggregate 'competitiveness upgrading' across the cluster [37].

Insights from different research streams move us closer to understanding platforms from the perspective of value co-creation. Platforms can form or promote the emergence of ecosystems enabling the co-production of innovations [25]. Much of this ability concerns the value-in-use dimension of the value co-creation concept, i.e., using and transferring value. Cluster platforms for joint action enable networked actors (producers, suppliers, customers) to exchange their knowledge, transfer value and reshuffle their resources for the purpose of direct coproduction of innovations [45].

Overall, digital platforms are redesigning traditional industrial landscapes towards ecosystemic perspective. Literatures on platforms and ecosystems have started to merge and have introduced the term 'platform ecosystem' (for example Basole \& Karla 54). Scholars are examining platform roles in ecosystems that generate large populations of networked users, who carry different functions and interact in a wide variety of ways to co-create value. This makes it reasonable to associate platforms with innovation ecosystems rather than with technological systems. And as studies on platforms suggest (McKinsey Global Institute, 2015 55), the digital sector provides several widely recognized examples of platforms and their associated platform leaders, such as Apple, Facebook, or Google (which became Alphabet) with each of these leaders playing an orchestrating role within a network of firms and individual innovators that have come to be collectively referred to as the platform's "innovation ecosystem" [56].

\subsection{Transition of economies to ecosystem organizational design}

Although the word 'ecosystem' derives linguistically from biological ecology, the use of this term in the context of innovation is not about connotations with Darwin's natural order. Rather it reflects the growing organizational complexity of economic systems, which denotes the formation of a new, more sophisticated social order, based on network coordination [27].

The shift of the technological paradigm [57] associated with non-linear innovation and proliferation of digital technologies is occurring hand in hand with a concomitant shift in the paradigm of social interactions. While industrial economies of mass production rested on a combination of market and hierarchic patterns of coordination, the emerging innovation-intensive economies (also called postindustrial systems, or knowledge-based economies) rely on a more sophisticated, network pattern of social coordination, constituting a functional hybrid between rigid hierarchies and atomistic markets [58, 59]. As applied to these changes, the term 'innovation ecosystem' can be used to denote the ongoing organizational transformation of economies into network-based production systems. This change is accompanied by a deconstruction of hierarchies both at micro- and macro-levels of social activity. In a growing number of countries private firms and 
public bodies are meeting the challenge of restructuring, transforming themselves from vertically built entities into more flexible and horizontally oriented $[47,60]$.

The newly emerging design of economies can be called ecosystemic, to emphasize the crucial role of networking and dynamic connectivity between actors (including interpersonal linkages) to work within the dispersed non-linear space. As a result, an innovation-conducive context is emerging. This context implies an inclusive institutional environment in the terms of Acemoglu and Robinson [61], or the idea of building 'commons' in terms of Ostrom [62], or simpler, the culture of win-win games in economic and political markets to meet challenges of the global competition.

As rigid vertical hierarchies, typical of the industrial era, are being replaced by agile horizontal networks, the traditional patterns of governance are giving way to collective decision-making, in which investment priorities, lines of business activity and conventions are defined through interactive consensus-building among networked actors. This non-hierarchic model of governance, associated with proliferation of platform-based communication, is often called collaborative governance [63].

Collaborative governance in its various patterns is now emerging for region-wide or national-wide innovation ecosystems that are gradually evolving within countries and territories under government support. Collaboratively governed ecosystems provide an alternative to the former, "linear" innovation systems of regional or national scale, which governments have tried to develop not through promoting collaboration and connectivity but through initiatives that concentrated on the individual roles of actors, or the establishment of innovative infrastructure or structures as such [64].

\subsection{The new mission of governments in the age of ecosystems. Policy implications.}

The global trend in the transformation of the hierarchical systems of the past into network-based and self-supportive ecosystems of the post-industrial era doesn't mean that the governments are becoming less active. On the contrary, governments' best interests require being even more proactive now than in the late industrial epoch, associated with liberalization of markets. However, the functional purpose and the manner of government interventions into markets are drastically changing.

In the industrial age, various national governments, especially in developing economies, took the upper hand in defining strategic priorities for the private sector, which was associated with a classical model of industrial policy. During times when modernization in many developing economies had been driven by their market-oriented transition, direct state interventions into industrial structures have been replaced by mild indirect initiatives aimed at building a better institutional environment.

The situation has changed in recent years, when all types of economies (developed, developing and those in transition) have been faced with a common need to accelerate their transition to knowledge-based systems and adapt themselves to the non-linear world. At the organizational level, this challenge is concerned with promotion of a network-based and ecosystem-oriented transformation. As a result, since 2010 s, a new model of industrial policy has emerged in many developed and developing countries, one which seeks to upgrade their industrial structure and enhance competitiveness through a collaborative organizational environment for a continual innovation [65].

The new industrial policy is not limited to manufacturing or to material goods. Rather it's about acceleration of the ecosystem-oriented restructuring in the whole industrial (economic) landscape, implying that under this new design the market forces will self-discover the most innovative business projects and re-direct resources into those projects and industries [66]. Under this policy, national governments don't seek to build specialized innovation clusters in "priority" industries, but instead help localities create platforms and infrastructures for networking and collaboration.

Though modern industrial policy is aimed at generating macro-level structural shifts, it is based on removing barriers at the micro-level, in order to cultivate organizational and social transformations through inter-firm and inter-organizational networking. The ecosystem approach implies that network linkages interconnect the micro- and macro levels of economies, corresponding to the core idea of Porter's Diamond model of competitiveness [40].

\section{Concluding findings}

The term "innovation ecosystem" symbolizes the newly emerging, network mode of arranging business activity and economic governance, which enables companies and territories to master innovation-led growth and benefit from rapid technological changes. This mode requires horizontal and inclusive economic thinking, as well as enabling certain organizational continua, relevant for interactive innovation and dispersed patterns of production. 
Innovation ecosystems can't be referred to as subjects of decision and action. Rather they are special organizational spaces, tailored to co-creation of values through collaboration. More exactly, they constitute a sophisticated milieu of actors, assets and linkages, generated by collaborative activities of networks. Such networks of various forms, sizes and profiles can play the role of modern-type organizations meant for a collective decision-making and collective action, and innovation ecosystems should be seen as the native environment of such networks. However, since collaborative networks and their ecosystems are functionally inseparable (in terms of interactive co-creation of value), both terms may be perceived and used interchangeably. This admission corresponds to findings in literature on complexity, viewing collaborative networks as complex adaptive systems that are inseparable from their changing environment by definition [66].

A multifaceted variety of ecosystem models, meant for various functional purposes, is now emerging and developing. Irrespective of their dispersed titles in different research streams, most of them can be referred to the class of innovation ecosystems, since the modern non-linear pattern of economic activity and economic growth is inherently connected with innovation. Our exploration of this variety through comparison of three different cases (platforms, clusters and value chains) suggests that all ecosystem models are complementary and predetermine each other in terms of design, pattern of collaboration and functionality.

Digital platforms, while coordinating broad groups of networked actors that interact in different functional combinations (consumers-consumers, consumers-producers, producers-producers), can be easily seen as universal tools to generate various kinds of ecosystems at various levels of social and economic activity. Platform-generated or platformenhanced ecosystems have their own platforms tailored either to co-usage or to co-production of innovations, or both. Regional clusters of triple-helix design can form advanced and convenient ecosystems to co-create innovations continuously, allowing clusters to serve as multi-faceted tools for upgrading industrial structures of modern economies. Meanwhile, collaboration between clusters of different geographical locations leads to the evolvement of GVCs and global production networks that can shape more powerful ecosystems, able to cocreate innovations continuously across the world.

Collaborative networks and hence innovation ecosystems may evolve and proliferate in the future across all sectors and levels of modern economies, be they region-wide, country-wide, or global-wide.
Plainly speaking, networks and their ecosystems shape the modern mode of production, making economies both more cohesive to meet the challenges of high uncertainty, and more innovative to become globally competitive and self-sustainable. Overall, innovation ecosystems concern the social, organizational and cultural shifts that facilitate the formation of the knowledge-based economy.

Social and economic ecosystems are surely not the same as natural ones. But both types are populations able to self-organize and self-develop in a similar, agile manner of complex adaptive systems, associated with inter-relationship of elements, as well as with the ability to adapt in and evolve with a changing environment [66], with mutual respect. In particular, the ecosystems can obtain new sources for growth and achieve dynamic sustainability through internal, self-correcting structural changes - rather than through top-down intervention of any centralized bodies, or from an external intervention, as typical for traditional systems.

All this supports the rationale for using the term 'ecosystem' far beyond a mere metaphor to systems, to highlight both the network-based organizational design and the collaborative organizational culture of the emerging innovation-led economies. Because of its relevance for the contemporary reality, it is no surprise that this term is widely popular in management studies and economics communities, as shown in our literature review.

Nevertheless, returning to publications that argue in favor of the classical term 'innovation systems', we admit that this option may still be regarded as a problem of academic taste in introducing contemporary realities. Some researchers may find it convenient to consider ecosystems as a new generation of systems and may respond by describing their growing complexity and ever changing features in the era of non-linear innovation. Others may prefer to call them ecosystems from the outset and underline the key role of collaborative interactions and value co-creation, including the historically new enabling role of government interventions.

In our view, the idea of ecosystems provides a much better image for effective policymaking across countries. It offers instructive insights on the framing and implementation of further research on innovation. Additionally, it acquires an especially important practical notion for the post-Soviet and other transition economies (in contrast to the situation in US and other technologically advanced nations), in which innovation systems are often perceived as special infrastructure projects realized by governments, and not as the result of networking and collaborative dialogue developed across the society. 


\section{References}

[1] World Economic Forum, The Global Competitiveness Report 2015-2016, World Economic Forum, Geneva, 2015.

[2] Lundvall, B.-Å., ed., National Systems of Innovation: Toward a Theory of Innovation and Interactive Learning, Pinter, London, 1992.

[3] Nelson, R.R., ed., National Innovation Systems: A Comparative Analysis, Oxford University Press, New York, NY, 1993.

[4] Edquist, C., ed., Systems of Innovation: Technologies, Institutions and Organizations, Pinter, London, 1997.

[5] Braczyk, H.-J., P. Cooke, and M. Heidenreich, eds., Regional Innovation Systems: The Role of Governances in a Globalized World, UCL Press, London, 1998.

[6] Malerba, F., ed., Sectoral Systems of Innovation: Concepts, Issues and Analyses of Six Major Sectors in Europe, Cambridge University Press, Cambridge, 2004.

[7] Bramwell, A., N. Hepburn, and D.A. Wolfe, Growing Innovation Ecosystems: University-Industry Knowledge Transfer and Regional Economic Development in Canada. Final Report to the Social Sciences and Humanities Research Council of Canada, 2012.

[8] Townsend, A., A.S.-K. Pang, and R. Weddle, Future Knowledge Ecosystems: The Next Twenty Years of Technology-Led Economic Development, IFTF Reports(SR-1236), 2009.

[9] Council on Competitiveness, Innovate America: Thriving in a World of Challenge and Change, Council on Competitiveness, Washington, DC, 2005.

[10] Oh, D.-S., F. Phillips, S. Park, and E. Lee, "Innovation Ecosystems: A Critical Examination", Technovation, 2016.

[11] Peltoniemi, M., Business Ecosystem: A Conceptual Model of an Organisation Population from the Perspectives of Complexity and Evolution, Tampere University of Technology, Tampere, 2005.

[12] Peltoniemi, M., "Preliminary Theoretical Framework for the Study of Business Ecosystems", Emergence: Complexity and Organization, 8(1), 2006, pp. 10-19.

[13] Manikas, K. and K.M. Hansen, "Software ecosystems - A systematic literature review", Journal of Systems and Software, 86(5), 2013, pp. 1294-1306.

[14] Pilinkiene, V. and P. Mačiulis, "Comparison of Different Ecosystem Analogies: The Main Economic Determinants and Levels of Impact", Procedia - Social and Behavioral Sciences, 156, 2014, pp. 365-370.

[15] Gawer, A., "Platform Dynamics and Strategies: From Products to Services", in Platforms, Markets and Innovation, A. Gawer, Editor. 2009. Edward Elgar: Cheltenham.

[16] Gawer, A. and M.A. Cusumano, "Industry Platforms and Ecosystem Innovation", Journal of Product Innovation Management, 31(3), 2014, pp. 417-433.

[17] Thomas, L.D.W., E. Autio, and D.M. Gann, "Architectural Leverage: Putting Platforms in Context", Academy of Management Perspectives, 28(2), 2014, pp. 198-219.
[18] Kortelainen, S. and K. Järvi, Ecosystems: Systematic Literature Review and Framework Development. XXV ISPIM Innovation Conference. Dublin, Ireland, 9-11 June 2014.

[19] Valkokari, K., "Business, Innovation, and Knowledge Ecosystems: How They Differ and How to Survive and Thrive within Them", Technology Innovation Management Review, 5(8), 2015.

[20] Suominen, A., M. Seppänen, and O. Dedehayir, Innovation Systems and Ecosystems: A Review and Synthesis. XXVII ISPIM Innovation Conference. Porto, Portugal, 19-22 June 2016.

[21] Aarikka-Stenroos, L., T. Peltola, A. Rikkiev, and U. Saari, Multiple Facets of Innovation and Business Ecosystem Research: The Foci, Methods and Future Agenda. XXVII ISPIM Innovation Conference. Porto, Portugal, 19-22 June 2016.

[22] Russell, M.G., J. Huhtamäki, K. Still, N. Rubens, and R.C. Basole, "Relational Capital for Shared Vision in Innovation Ecosystems", Triple Helix, 2(1), 2015, p. 1-36.

[23] Wessner, C.W., "Entrepreneurship and the Innovation Ecosystem Policy Lessons from the United States", in Local Heroes in the Global Village: Globalization and the New Entrepreneurship Policies, D.B. Audretsch, H. Grimm, and C.W. Wessner, Editors. 2005. Springer: New York, NY.

[24] European Commission, Digital Business Ecosystems, Office for Official Publications of the European Communities, Luxembourg, 2007.

[25] Ranjan, K.R. and S. Read, "Value Co-creation: Concept and Measurement", Journal of the Academy of Marketing Science, 44(3), 2016, pp. 290-315.

[26] Roser, T., A. Samson, P. Humphreys, and E. CruzValdivieso, Co-creation: New pathways to Value, LSE Enterprise - Promise Corporation, London, 2009.

[27] MacGregor, S.P. and T. Carleton, eds., Sustaining Innovation: Collaboration Models for a Complex World, Springer, New York, NY, 2012.

[28] Camarinha-Matos, L.M. and H. Afsarmanesh, "Concept of Collaboration", in Encyclopedia of Networked and Virtual Organizations, G.D. Putnik and M.M. Cruz-Cunha, Editors. 2008. IGI Global: Hershey, PA.

[29] Drucker, P.F., Post-Capitalist Society, ButterworthHeinemann, Oxford, 1993.

[30] Gloor, P.A., Swarm Creativity: Competitive Advantage Through Collaborative Innovation Networks, Oxford University Press, New York, NY, 2006.

[31] Camarinha-Matos, L.M. and H. Afsarmanesh, "Classes of Collaborative Networks", in Encyclopedia of Networked and Virtual Organizations, G.D. Putnik and M.M. Cruz-Cunha, Editors. 2008. IGI Global: Hershey, PA.

[32] Nieto, M.J. and L. Santamaría, "The Importance of Diverse Collaborative Networks for the Novelty of Product Innovation", Technovation, 27(6-7), 2007, pp. 367-377.

[33] Russell, M.G., K. Still, J. Huhtamäki, C. Yu, and N. Rubens, Transforming Innovation Ecosystems through 
Shared Vision and Network Orchestration. Triple Helix IX International Conference. Stanford, CA, USA, 11-14 July 2011.

[34] Jucevičius, G. and K. Grumadaite, "Smart Development of Innovation Ecosystem", Procedia Social and Behavioral Sciences, 156, 2014, pp. 125129.

[35] Martin, R. and P. Sunley, "Complexity thinking and evolutionary economic geography", Journal of Economic Geography, 7(5), 2007, pp. 573-601.

[36] Martin, R. and P. Sunley, "Conceptualizing Cluster Evolution: Beyond the Life Cycle Model?", Regional Studies, 45(10), 2011, pp. 1299-1318.

[37] Porter, M.E. and C.H.M. Ketels, "Clusters and Industrial Districts: Common Roots, Different Perspectives", in A Handbook of Industrial Districts, G. Becattini, M. Bellandi, and L. De Propis, Editors. 2009. Edward Elgar: Cheltenham.

[38] van Winden, W., L. van den Berg, L. Carvalho, and E. van Tuijl, Manufacturing in the New Urban Economy, Routledge, Abingdon, 2011.

[39] Etzkowitz, H. and L. Leydesdorff, "The Dynamics of Innovation: From National Systems and "Mode 2" to a Triple Helix of University-Industry-Government Relations", Research Policy, 29(2), 2000, pp. 109-123.

[40] Porter, M.E., The Competitive Advantage of Nations, Free Press, New York, NY, 1990.

[41] Delgado, M., M.E. Porter, and S. Stern, "Clusters, Convergence, and Economic Performance", Research Policy, 43(10), 2014, pp. 1785-1799.

[42] Ffowcs-Williams, I., Cluster Development - The GoTo Handbook: Building Competitiveness through Smart Specialisation, Cluster Navigators, Nelson, 2012.

[43] Lindqvist, G., C.H.M. Ketels, and Ö. Sölvell, The Cluster Initiative Greenbook 2.0, Ivory Tower, Stockholm, 2013.

[44] Napier, G. and S. Kethelz, The Welfare Technological Ecosystem in the Region of Southern Denmark, REG X - The Danish Cluster Academy, Copenhagen, 2014.

[45] Sölvell, Ö., Clusters - Balancing Evolutionary and Constructive Forces, $2^{\text {nd }}$ edn., Ivory Tower, Stockholm, 2009.

[46] Huhtamäki, J., M.G. Russell, K. Still, and N. Rubens, "A Network-Centric Snapshot of Value Co-Creation in Finnish Innovation Financing", Open Source Business Resource, March 2011.

[47] Sölvell, Ö., "The Multi-Home-Based Corporation: Solving an Insider-Outsider Dilemma", in Innovation and Institutional Embeddedness of Multinational Companies, M. Heidenreich, Editor. 2012. Edward Elgar: Cheltenham.

[48] Tiwana, A., B. Konsynski, and A.A. Bush, "Research Commentary -Platform Evolution: Coevolution of Platform Architecture, Governance, and Environmental Dynamics", Information Systems Research, 21(4), 2010, pp. 675-687.

[49] Evans, D.S., Platform Economics: Essays on MultiSided Businesses, Competition Policy International, London, 2011.
[50] Parker, G.G., M.W. van Alstyne, and S.P. Choudary, Platform Revolution: How Networked Markets Are Transforming the Economy - And How to Make Them Work for You, W.W. Norton \& Co., New York, NY, 2016.

[51] Gawer, A., "Bridging Differing Perspectives on Technological Platforms: Toward an Integrative Framework", Research Policy, 43(7), 2014, pp. 12391249.

[52] Sölvell, Ö., G. Lindqvist, and C.H.M. Ketels, The Cluster Initiative Greenbook, Ivory Tower, Stockholm, 2003.

[53] Ketels, C.H.M., Clusters, Cluster Policy, and Swedish Competitiveness in the Global Economy, Expert Reports to Sweden's Globalisation Council (30), 2009.

[54] Basole, R.C. and J. Karla, "On the Evolution of Mobile Platform Ecosystem Structure and Strategy", Business \& Information Systems Engineering, 3(5), 2011, pp. 313-322.

[55] McKinsey Global Institute, Digital America: A Tale of the Haves and Have-Mores, McKinsey \& Company, New York, NY, 2015.

[56] Gawer, A., "The Organization of Technological Platforms", in Technology and Organization: Essays in Honour of Joan Woodward, N. Phillips, G. Sewell, and D. Griffiths, Editors. 2010. Emerald Group Publishing.

[57] Ivanova, I.A. and L. Leydesdorff, "Rotational Symmetry and the Transformation of Innovation Systems in a Triple Helix of University-IndustryGovernment Relations", Technological Forecasting and Social Change, 86, 2014, pp. 143-156.

[58] Powell, W.W. and S. Grodal, "Networks of Innovators", in The Oxford Handbook of Innovation, J. Fagerberg, D.C. Mowery, and R.R. Nelson, Editors. 2005. Oxford University Press: Oxford.

[59] Williamson, O.E., "The Economics of Governance", American Economic Review, 95(2), 2005, pp. 1-18.

[60] Smith-Doerr, L. and W.W. Powell, "Networks and Economic Life", in The Handbook of Economic Sociology, N.J. Smelser and R. Swedberg, Editors. 2005. Princeton University Press: Princeton, NJ.

[61] Acemoglu, D. and J.A. Robinson, Why Nations Fail: The Origins of Power, Prosperity and Poverty, Profile Books, London, 2012.

[62] Ostrom, E., Governing the Commons: The Evolution of Institutions for Collective Action, Cambridge University Press, Cambridge, 1990.

[63] Ansell, C.K. and A. Gash, "Collaborative Governance in Theory and Practice", Journal of Public Administration Research and Theory, 18(4), 2007, pp. 543-571.

[64] European Commission, Smart Guide to Cluster Policy, European Commission, Brussels, 2016.

[65] Warwick, K., Beyond Industrial Policy: Emerging Issues and New Trends, OECD Science, Technology and Industry Policy Papers (2), 2013.

[66] Chan, S., Complex Adaptive Systems. ESD.83 Research Seminar in Engineering Systems. 31 October / 6 November, 2001. 